\title{
External Acoustic Meatus
}

National Cancer Institute

\section{Source}

National Cancer Institute. External Acoustic Meatus. NCI Thesaurus. Code C12498.

A part of the ear canal that is external to the ear drum. 